\title{
DEVELOPMENT OF YOUNG VARYING LEMMINGS (Dicrostonyx)
}

\author{
Richard M. Hansen*
}

\footnotetext{
$\mathbf{0}$
} N June 28, 1955 a female varying lemming (Dicrostonyx groenlandicus rubricatus (Richardson)) and her nine young were captured on the east side of Umiat Lake, Umiat, Alaska. The young were estimated to have been 3 days old. The female and her litter were kept in captivity for a period of 6 weeks in Alaska and later were transported to Fort Collins, Colorado. Four of the young survived, reproduced and established the laboratory colony upon which this study is based.

Owing to the various peculiarities that these animals possess, much interesting information can be obtained from the study of a laboratory colony. Animals of the genus Dicrostony $x$ are reputed to be the only rodents that molt into a white winter pelage (Anderson and Rand, 1945; Hall and Cockrum, 1953). Miller (1896) described their detailed morphology; Manning (1954) remarked upon reproduction, sex ratio, and life expectancy of these animals, both in nature and in captivity. Degerb $\varnothing \mathrm{l}$ and M $\phi \mathrm{hl-Hansen} \mathrm{(1943)} \mathrm{reported}$ upon breeding conditions and molting, and also included observations on the development of the young. Because some of the developmental features of the animals from Alaska were different from those reported by Degerbøl and Møhl-Hansen, and since so little is known about their development, it was deemed necessary to study the young in detail. Therefore, the captive colony was observed with the aim of obtaining data on growth and morphology. These would make possible a more accurate determination of the age of young animals collected in the field. In view of the fact that my animals were maintained under artificial conditions, the results should be accepted with some reservations, and confirmatory tests in both laboratory and field are needed.

I wish to express my appreciation to the Arctic Research Laboratory, Office of Naval Research, and to the Arctic Institute of North America for support of field work during the summer of 1955, and to Frank A. Pitelka, Museum of Vertebrate Zoology, University of California, under whose sponsorship my field work was conducted. He also read the manuscript of this paper and offered many suggestions. I should especially like to thank G. D. Hanna, then Director of the Arctic Research Laboratory, and his staff for assistance with preparations for field work.

*Colorado Agricultural Experiment Station, Colorado State University, Fort Collins, Colorado. 
Materials and Methods. Observations were made on and data were obtained from several adults and thirteen litters; however, weight measurements are reported from only eight litters with a total of fifty-two young, produced by four different females. Mortality between birth and 40 days was approximately 20 per cent; that is, forty-one of the fifty-two animals survived to become 40 days old. Mortality was higher in the litters not included in the weight-growth measurements. The animals were kept in wooden boxes with open tops and dried beet pulp litter; cigar boxes were provided for nesting boxes, nesting material consisted of cotton and tissue paper. Food consisted of rolled oats, lettuce, cabbage, apples, and yams which were provided in adequate amounts at all times. When the young were from 17 to 20 days old, each individual was isolated in a single cage, although two young were occasionally housed together until they were approximately 30 days of age. Reproductively active males and females were housed individually as the females fight and males are often killed by females (See Manning, 1954).

In the early stages of their development the young were weighed every second day, while during the later stages the weighings were less frequent. Behaviour and molt were studied during the periods when the young were taken out of the nest for weighing. After the young had left the nest, more time was devoted to observation of behaviour and development of hair and the changes in pelage were observed daily.

\section{General Development}

Newborn Animals. In newborn animals, the body is covered with loose, wrinkled skin. The dorsum is redder and more heavily pigmented than the remainder, which is pinkish. Short, black bristles are present on the lips, and vibrissae occur on the sides of the rostrum (see Fig. 1). Eight depressions are present on the belly surface indicating eight mammae (four pectoral, four inguinal). The toes are short, bulbous distally, and each is provided with a claw. The pollex is small and rudimentary. The tail is short and naked. The incisor teeth have not erupted. The eyelids are fused. The ears are small, obscure, and closed. When disturbed or when taken from the nest and laid on a smooth surface they attempt to right themselves; they lie, flexed ventrally, on either their sides or on the back. In the nest they are largely inactive and lie motionless, except when disturbed or nursing. The young are capable of vocalization immediately after birth. They possess a shrill, high-pitched voice that can be heard at a distance of at least 4 metres.

The weights of thirty-four newborn animals varied from $2.7 \mathrm{gm}$. to 4.8 gm. and averaged $3.8 \mathrm{gm}$. (see Fig. 3); the crown-rump length varied from 20 to $27 \mathrm{~mm}$.

Fig. 1. The successive stages in the development of hair from newborn to 12 days of age. The figures give the age in days. 

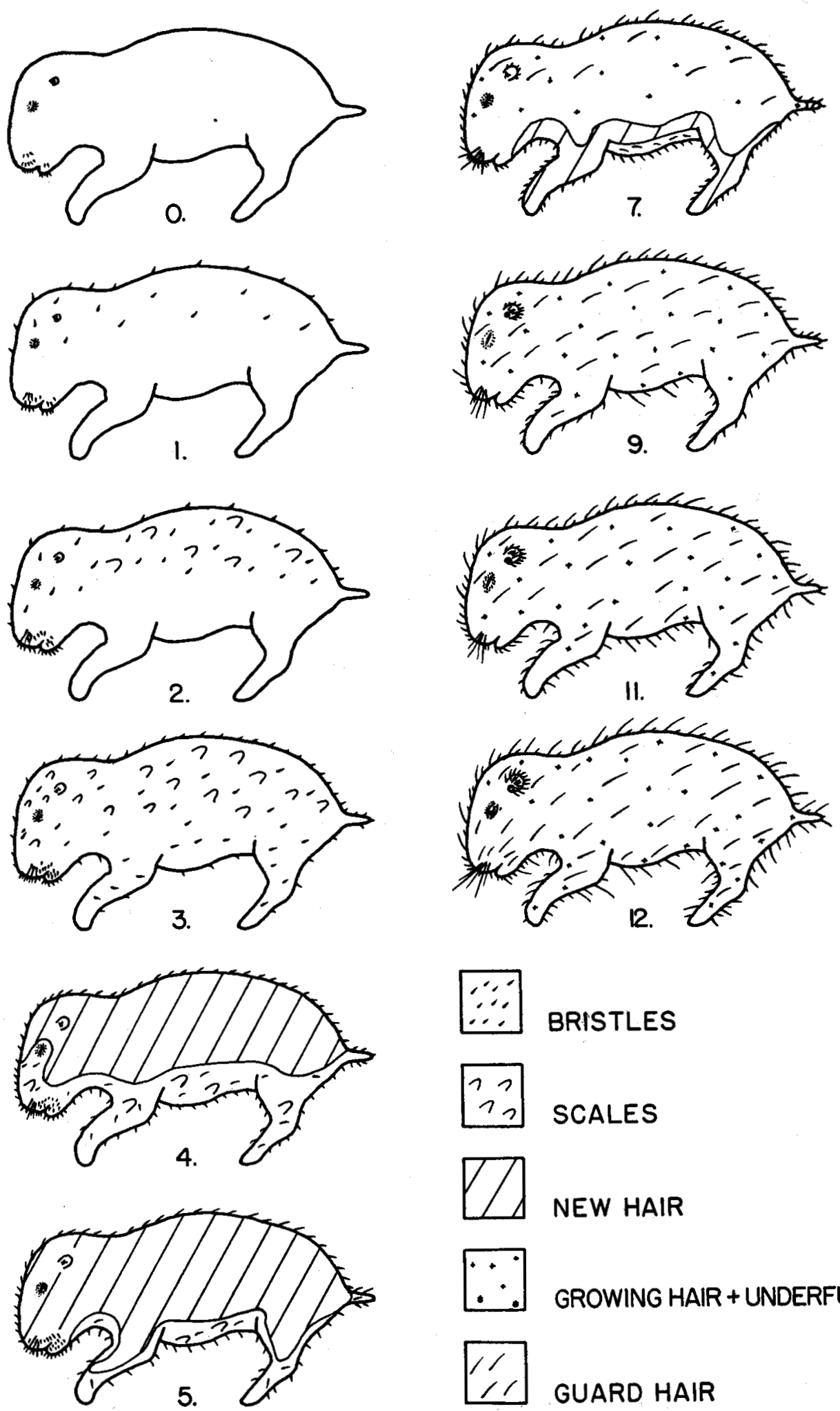

NEW HAIR

$\because \because$ GROWING HAIR + UNDERFUR

$\because /$, GUARO HAIR 
Development of Hair. Bristles become more numerous and are present on the head and dorsum on the second day. They spread ventrally and eventially cover all surfaces of the body by the third day. Scales appear on the dorsum on the second day and spread ventrally on the third and fourth days (Fig. 1). Pigmentation increases with age and by the third day the skin is darkened by developing hair follicles that lie beneath the skin. The middorsal stripe area is especially dark. On the fourth day the young lose the wrinkled appearance of the skin and the tips of new hairs occur on the crown of the head and dorsum. The first hairs are bristle-like and the tips are banded with varied colours. Presumably these varicoloured hairs develop into "pile hairs". The new hairs spread ventrad in subsequent development and at 8 days of age the young are completely covered with hair, except on the areas between the legs. The dorsum is the first area to gain guard hairs and underfur. On the seventh day short, dense underfur is noted beneath the pile hairs and the guard hairs are slightly elongated beyond the pile hairs. The ears gain new hairs on the seventh day. The underfur and guard hairs grow and spread ventrad. At the age of 12 days the young have a dense, immature pelage. Hair growth continues beyond 12 days and by 15 days of age the pelage appears to have almost completed its growth and is harsh in texture.

Subadult Pelage. The first indications of the subadult pelage occur in animals that are from 26 to 30 days old (Fig. 2). The advent of new pelage is indicated by the appearance of short, stiff hairs beneath the immature pelage along the mammillary lines. The areas of eruption of new hair spread medially and dorsally from the mammillary lines. Two to three days after their initiation, newly erupting hairs have spread to all of the venter and dorsad to invest the shoulders and hips. The eruption and growth follow an anterodorsal direction. The crown of the head is the last area to gain new hairs. Some individuals may gain new hair even prior to the appearance of a molt line, but the molt line (if present) lags from 1 to $3 \mathrm{~cm}$. behind the appearance of new hairs, and is not observable until the new growth is nearly completed. In this respect, the subadult molt is similar to the preliminary, and final autumn moits of the varying hare (Lyman, 1954: 404), in which the new hairs actually grow past the old, anchored hairs without removing them from their common sockets. The new hairs grow to nearly their full length and it is the large anchoring base pushing against the old anchored hair that actually dislodges the latter. The subadult pelage has usually completed its growth in 7 to 14 days following the first appearance of new hairs on the ventral body surfaces.

It would be interesting to know why the development of hairs at 4 days of age is initiated on the dorsum, whereas that of the subadult pelage begins on the venter. In adult varying lemmings the spring molt begins on the dorsum and develops in a posteroventral direction, whereas the fall molt begins

Fig. 2. The changes of pelage from the immature to the subadult. Average ages in days for the different stages of molt are given. The molt line is indicated by the junction between "subadult" and "growing hairs". 
DEVELOPMENT OF YOUNG VARYING LEMMINGS
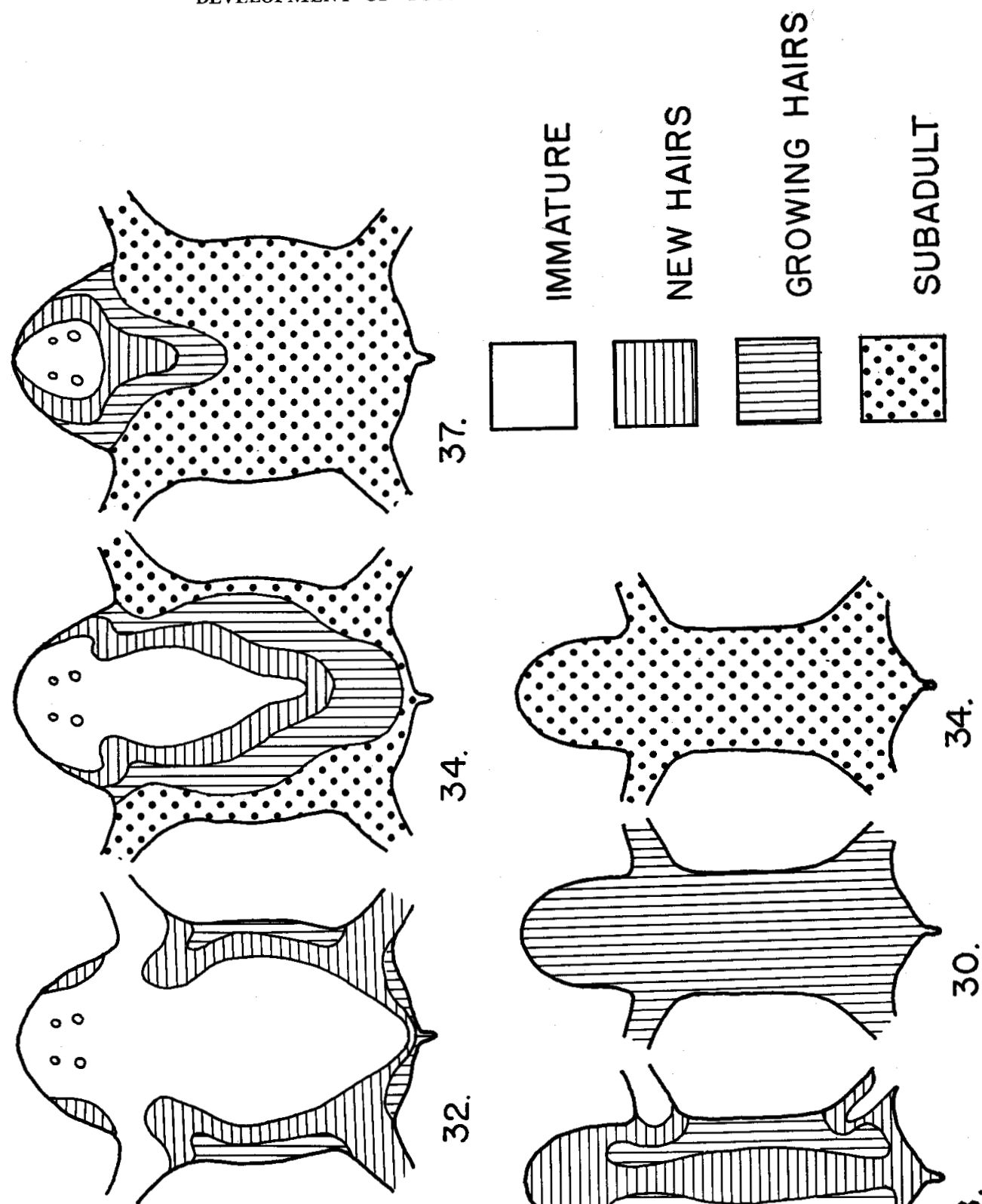

(1)
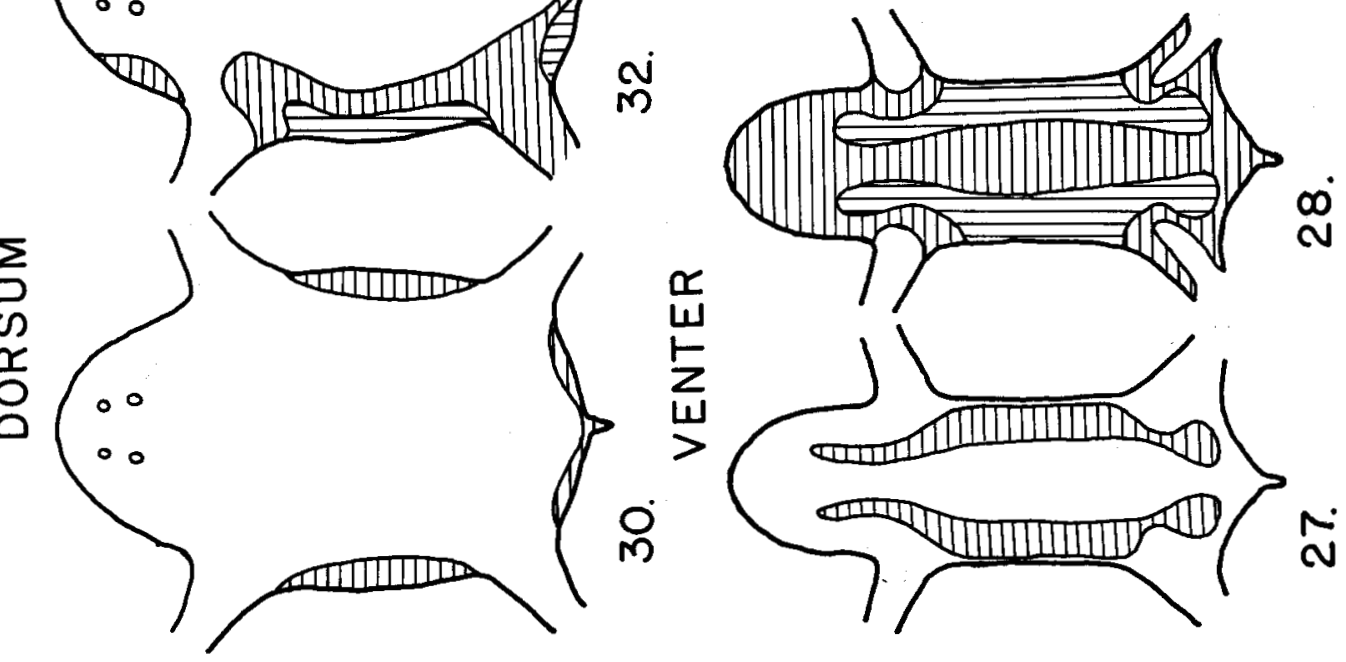
on the venter and is directed dorso-anteriorly (Degerbøl and Møhl-Hansen, 1943). This is essentially the same type of hair replacement that occurs in some subgenera of ground squirrels and other sciurids (Hansen, 1954). The subadult molt and fall molt of the varying lemming follow the same course of development, whereas the development of hair at 4 days of age has a pattern resembling more closely the spring molt. The harvest mouse (Micromys minutus soricinus) was reported by Kästle (1953) as having the same pattern of hair development and change in subadult pelage that $I$ found in varying lemmings.

Coat colour is extremely variable and at present poorly understood. The colours of adults in my colony were similar to those reported by Degerb $\varnothing 1$ and Møhl-Hansen for the Greenland varying lemmings that they kept in captivity. In my colony the young varied from whitish to reddish, the majority being dark and similar in colour to young born in the summer.

Eyes, ears, teeth, claws. As growth and development proceed the eyes enlarge and open on the twelfth day. Degerb $\varnothing l$ and Møhl-Hansen (1943) report that the eyes of the Greenland varying lemmings are not yet open by the twelfth day but are open by the fourteenth day. I have observed only one lemming in my colony whose eyes remained closed beyond 12.5 days of age, and its eyes were open at 13 days of age. Although the young are born toothless, the incisor teeth are observable beneath the skin of the gums on the third day; by the fourth they are puncturing the gums; and on the fifth they have erupted and are prominent. In captive lemmings from Greenland, Degerb $\varnothing \mathrm{l}$ and $M \varnothing h l-H a n s e n$ report that the front teeth are hidden in the gums until 14 days of age. The cheek teeth are lying beneath the skin in preserved 3-day old specimens. The first upper molars have erupted in specimens 7 days old and all cheek teeth are prominent in those 10 days old. The ears are small and obscure at birth. By the ninth day the external ears begin to open; on the tenth day they are definitely open but do not function efficiently until the eleventh day; presumably the auditory canal remains closed until then. Varying lemmings are born with claws on all toes. The pollex is naked and rudimentary. At 25 days of age, animals born in the summer have "summer claws" while those born in the winter have enlarged "bifid" claws on the third and fourth digits of the front feet. The appearance of bifid claws is preceded by an enlargement of the toe pads on the third and fourth digits of the front feet. Young that have bulbous toe pads on these digits at 10 to 14 days of age, will have developed bifid claws at 25 days of age. There was no apparent correlation between coat colour and bifid claws, since all young born in the winter developed bifid claws, although their pelages varied from whitish to reddish.

Behaviour. One day: the young can crawl feebly with their front feet; they indiscriminately rest on their belly, sides, or back; vocal sounds are infrequent. Three days: the young crawl with difficulty. Four days: the young are capable of crawling, mainly with the front feet. Five days: the 


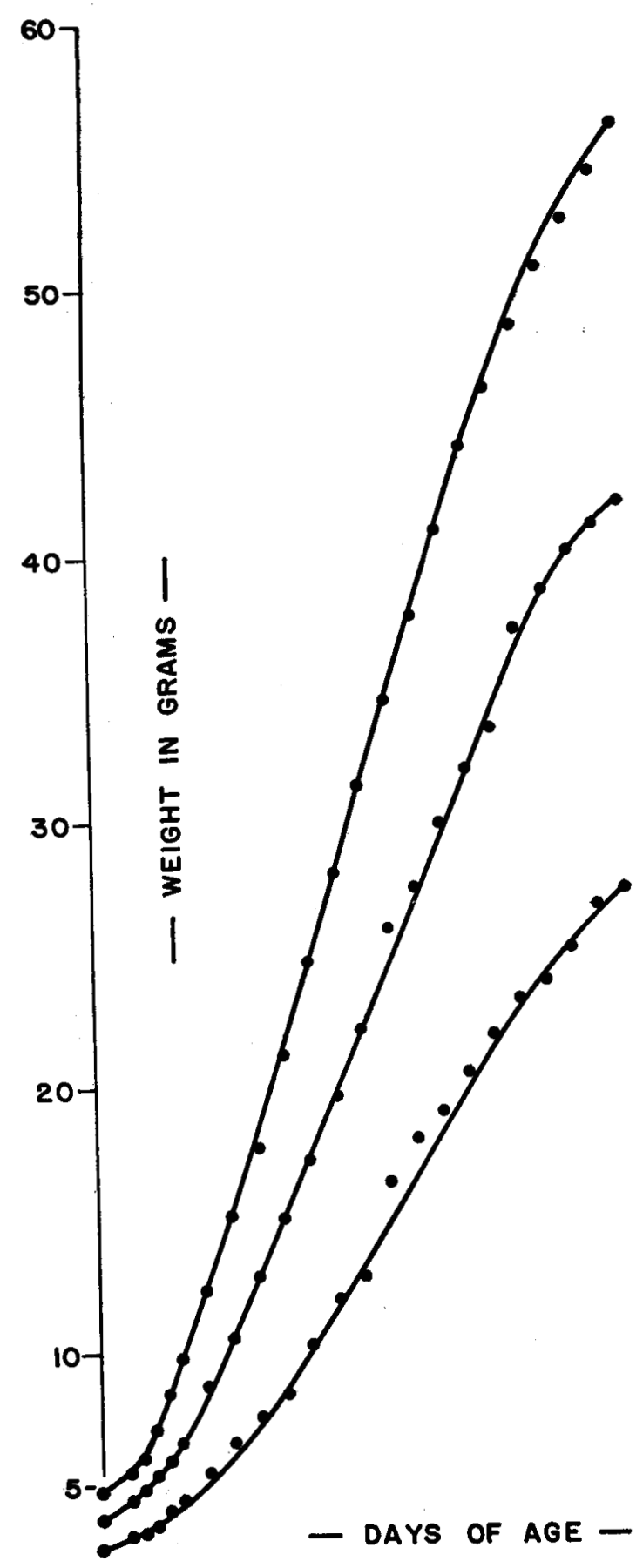

Fig. 3. The averages

and extremes in

weight of young

varying lemmings

from shortly after

birth to 40 days

of age.

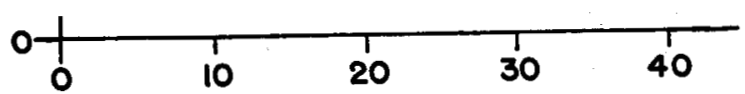


young are capable of more complex movements and move their hind legs feebly while crawling; they are able to maintain an unsteady balance and climb an incline. Seven days: they crawl rather efficiently on all four feet but remain unsteady in doing so; the submissive response to being picked up by the scruff is present, but not strongly developed. Ten days: the submissive response to being picked up by the scruff is strongly developed. Eleven days: the young are able to detect sounds, as is shown by the fact that they will of ten run out of the nest when the nesting box is scratched; they can stand feebly on all four legs. Twelve days: the eyes are open and the young travel to all parts of the cage; they are extremely sensitive to sounds and make quick movements in response to loud noises. Thirteen days: the young spend more time out of the nesting box; they maintain a steadier balance while walking and can scratch themselves behind the ears with the hind feet. Fourteen days: the young eat green plants, rolled oats and other food items when outside the nesting box; behaviouristic traits suggestive of "gentle" fighting and play are discernible; the submissive response to being picked up by the scruff is somewhat reduced and the female no longer returns the young to the nest. Sixteen days: the young take food in liberal quantities and the behaviour of the female indicates that the young are being weaned; all young are frequently seen eating together outside of the nest. Seventeen days: the young are able to climb on a tread wheel and turn it slowly. Eighteen days: the female tries to avoid the young and to prevent them from nursing, although the young frequently pursue the mother and attempt to nurse. Nineteen days: the young run on the tread wheel. Twenty days: the young attempt to avoid being caught; their defensive attitude, however, is not strongly developed. Twenty-two days: the young have a more strongly developed defensive attitude, they click their teeth, utter loud adult-like squeaks and have lost the submissive response when picked up by the scruff. Twenty-tbree days: the young frequently attempt to bite and scratch when being caught; the clicking of their teeth suggests a defensive attitude; young at this age sometimes develop a hierarchy if left together, and the first signs of intense fighting are observed. The young exhibit an "alarm" response and show behaviour that is interpreted as fright. They often run quickly into their nesting boxes when approached or when loud noises are made. Twenty-five to forty days: the behaviouristic traits become progressively more adult-like and beyond 30 days of age the behaviour does not differ significantly from that of adults.

Sexual Maturity. The minimum age at which young varying lemmings breed is not accurately known. Manning (1954: 37) reported one female which produced a litter when 84 days old and a male which sired a litter when 46 days old. I have recorded one female which gave birth to a litter when she was 49 days old ( 20 days gestation). Field data taken from animals trapped at Umiat, Alaska, also indicate that females may naturally breed at early ages. For example, a female weighing 29.3 gm., taken on July 31, 1955, contained five embryos, $5 \mathrm{~mm}$. in length. She possessed immature pelage and when compared with young of known ages she was estimated to have been approxi- 
mately 28 to 30 days old. Another female weighing 38.0 gm., taken at the same time at Umiat, contained five embryos, $4 \mathrm{~mm}$. in length. This animal was in the process of acquiring its subadult pelage and was estimated to have been 34 days old. Examination of captive young showed that the vagina remains imperforate until the young attain an age of 25 to 27 days. At this age the vagina becomes swollen and perforate. According to these data females are apparently capable of copulating and producing gametes when 25 to 30 days old.

The loss of the pubic symphysis and formation of a "gap" do not appear to take place in varying lemmings as it does in pocket gophers. Hisaw (1924) reported absorption of the symphysis to take place in the gopher before copulation (p. 94), and found no evidence to indicate that the symphysis is restored after parturition. I have not observed the presence of a "gap" in female varying lemmings prior to copulation, and have only noted its presence in pregnant females. Three females which were kept isolated from males developed closed pubes 25 days after parturition. Guilday (1951) stated that in Microtus pennsylvanicus "there does not appear to be any evidence of resorption of part of the pubic bones ... rather there is a lateral movement of both innominates to facilitate parturition". This may also be the way in which the pubic "gap" is formed and lost in varying lemmings.

Growth. Gains in weight of young varying lemmings are shown in Figs. 3 and 4. Morrison et al. (1954) described the growth in weight of varying lemmings from birth to 20 days as "a simple, straight line". I found this is not true for larger samples than available to them, but that weights increase in a typical sigmoidal relation with age. The weights of young taken shortly after birth averaged $3.8 \mathrm{gm}$., with extremes of $2.7 \mathrm{gm}$. and $4.8 \mathrm{gm}$. Fig. 3 shows a relatively slow increase in weight to about 4 days of age, at which time the weights range between $3.5 \mathrm{gm}$. and $7.2 \mathrm{gm}$. and average approximately $5.4 \mathrm{gm}$. Between the fifth and twenty-second day, however, weight increases much more rapidly. At 22 days of age the range of variation is from $16.5 \mathrm{gm}$. to $34.6 \mathrm{gm}$., and the average approximately $26.0 \mathrm{gm}$. The rate of increase in weight starts slowing down near the twenty-second day, and the curve tends to begin leveling off near 40 days. At 40 days of age, subadult animals vary in weight from about $28.0 \mathrm{gm}$. to $56.3 \mathrm{gm}$., with an average weight of $42.0 \mathrm{gm}$. As weights increase from birth to 40 days of age there is also an increase in the range of variation. Individuals of the same litter, as well as the composite growths of all litters show increased variation with age (Figs. 3 and 4). Beyond 40 days of age the rate of increase in weight does not slow down as rapidly for smaller animals as it does for larger animals (Fig. 3).

Remarks. Listed in Table 1 are the various ages at which certain developmental features are acquired by the young of some microtines. At Umiat, Alaska, it was not uncommon to take Microtus oeconomus and Cletbrionomys rutilus in the same runways with varying lemmings. The other data are for 
microtines from more southern latitudes and varying lemmings from various geographic areas.

According to Table 1, it is apparent that varying lemmings from Umiat develop at about the same rate as Cletbrionomys and Lagurus, slower than Microtus and much faster than Phenacomys. Specific differences as well as geographic differences in rate of development are shown. For example, $M$. oeconomus develops slower than its more southerly relative $M$. pennsylvanicus; and $M$. oregoni develops slower still. Apparently varying lemmings from Alaska develop faster than those from Greenland although they may develop slower than those from Northern Canada.

Table 1. Comparison of developmental features of some microtines.*

\begin{tabular}{|c|c|c|c|c|c|}
\hline & $\begin{array}{l}\text { incisors } \\
\text { erupt }\end{array}$ & $\begin{array}{l}\text { cheek teeth } \\
\text { erupt }\end{array}$ & $\begin{array}{l}\text { eyes } \\
\text { open }\end{array}$ & $\begin{array}{l}\text { auditory } \\
\text { canals open }\end{array}$ & weaned \\
\hline $\begin{array}{c}\text { Microtus pennsylvanicus } \\
\text { (Bailey, 1924) }\end{array}$ & 5 & 7 & about 8 & about 8 & 12 \\
\hline (Hamilton, 1941) & $6-7$ & - & 8 & 8 & $12-13$ \\
\hline $\begin{array}{l}\text { Microtus oregoni } \\
\quad \text { (Svihla, 1932) }\end{array}$ & - & - & $10-11$ & - & 15 \\
\hline (Cowan \& Arsenault, 1954) & $51 / 2$ & $111 / 2$ & $10-11 \frac{1}{2}$ & 10 & 13 \\
\hline $\begin{array}{l}\text { Microtus oeconomus } \\
\quad \text { (Morrison et. al., 1954) }\end{array}$ & 9 & - & $9(-10 ?)$ & closed at 9 days & - \\
\hline $\begin{array}{l}\text { Microlus californicus } \\
\quad \text { (Selle, 1928) }\end{array}$ & - & - & $9-10$ & - & - \\
\hline $\begin{array}{l}\text { Lagurus curtalus } \\
\text { (James \& Booth, 1954) }\end{array}$ & - & - & $9-13$ & - & 21 \\
\hline $\begin{array}{c}\text { Clethrionomys gapperi } \\
\text { (Benton, 1955) }\end{array}$ & $7-8$ & - & $12-13$ & - & 17 \\
\hline $\begin{array}{l}\text { Clethrionomys rutilus } \\
\quad \text { (Morrison, et. al., 1954) }\end{array}$ & 9 & - & $10-11$ & $8-9$ & - \\
\hline $\begin{array}{l}\text { Dicrosionyx groenlandicus } \\
\text { Greenland } \\
\text { (Degerb } \varnothing 1 \text { \& M } \varnothing \mathrm{hl}-\text { Hansen, 1943) }\end{array}$ & about 13 & - & $13-14$ & - & 18 \\
\hline $\begin{array}{l}\text { Barter Island, Alaska } \\
\text { (Strecker \& Morrison, 1952) }\end{array}$ & 8 & - & 14 & closed at 7 days & - \\
\hline Colony from Umiat & 5 & $7-9$ & 12 & 11 & 17 \\
\hline $\begin{array}{l}\text { Northern Canada } \\
\text { (Manning, 1954) }\end{array}$ & - & - & - & - & 14 \\
\hline $\begin{array}{c}\text { Phenacomys longicaudus } \\
\text { (Howell, 1926) }\end{array}$ & - & - & 19 & - & 29 \\
\hline
\end{tabular}

*Time in days.

One might expect faster development and higher growth rates in the young of microtines which live successfully in the extremes imposed upon them by the rigorous arctic environment. Both these factors will influence the age at which the young can leave the nest and forage for themselves. However, it is not apparent in these data that microtines living in the arctic have a higher developmental rate than those from farther south. Rather, it seems that the rates of development are inherent characteristics of populations that may be correlated with factors other than climate. In microtine rodents maternal care and behaviour are perhaps more important to survival than rate of growth or development. 


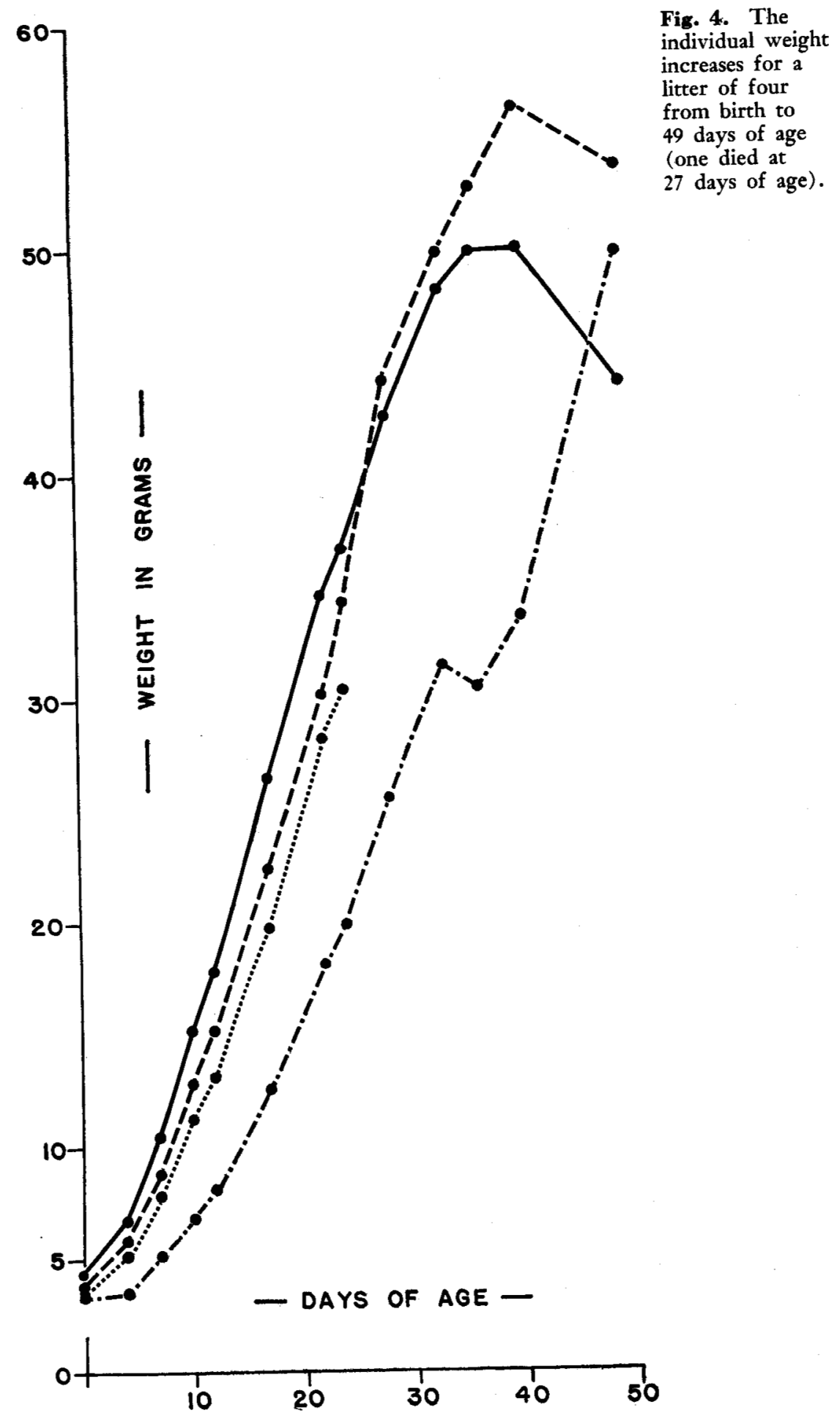


Summary. Growth and development of young varying lemmings (Dicrostony $x$ groenlandicus rubricatus) were studied. The general development of young from the time they were born until they were 40 days old is presented. Young possess bristles on their lips, and vibrissae on the sides of the rostrum at birth. Four days: the dorsum becomes covered with short, stiff hair. Five days: incisor teeth are prominent. Six days: the young crawl on all four feet. Eight days: all body surfaces are covered with hair but growth of hair continues until the age of 15 days. Nine days: the external ears are open but the ears do not function efficiently before the eleventh day. Twelve days: the eyes open and the young wander about the cage. Fourteen days: the young eat food other than milk supplied by the mother. Eigbteen days: the young are completely weaned although they pursue the mother and attempt to nurse. Twenty days: the young develop a defensive behaviour. Twenty-two days: the young chatter, click their teeth and often bite or scratch when handled. Twenty-six to thirty days: short stiff hairs appear on the belly beneath the immature pelage, this is the first indication of subadult pelage. The course of development of subadult pelage is directed dorso-anteriorly.

Sexual maturity is reached in some females at 25 to 30 days of age. At this time they still possess their immature pelage. The vagina becomes perforate in females at 25 to 27 days of age.

The bifid claws of the third and fourth digits of the front feet are present in immature animals born in winter. The bifid claws have not been observed in immatures born during the summer.

At birth, young weigh an average of $3.8 \mathrm{gm}$. (extremes, $2.7 \mathrm{gm}$. and 4.8 gm.). Weight increases relatively slowly until 4 days, at which time the young average $5.4 \mathrm{gm}$. (extremes, $3.5 \mathrm{gm}$. and $7.2 \mathrm{gm}$.). The most rapid growth occurs between 5 and 22 days of age. At 22 days the weights average $26.0 \mathrm{gm}$. (extremes, $16.5 \mathrm{gm}$. and $34.6 \mathrm{gm}$.). The rate of increase in weight begins to decline beyond 22 days and tends to start leveling off at 40 days of age. At 40 days weights average $42.0 \mathrm{gm}$. (extremes, 28.0 and $56.3 \mathrm{gm}$.).

\section{References}

Anderson, R. M. and A. L. Rand. 1945. The varying lemming (Genus Dicrostonyx) in Canada. J. Mamm. 26: 301-6.

Bailey, V. 1924. Breeding, feeding, and other life habits of meadow mice (Microtus). J. Agr. Res. 27: 523-35.

Benton, A. H. 1955. Notes on the behavioral development of captive red-backed mice. J. Mamm. 26: 566-7.

Cowan, I. M. and M. G. Arsenault. 1954. Reproduction and growth of the creeping vole, Microtus oregoni serpens Merriam. Can. J. Zool. 32: 198-208.

Degerbøl, M. and U. Møhl-Hansen. 1943. Remarks on the breeding conditions and molting of the Collared Lemming (Dicrostonyx). Medd. om Grønl. 131 No. 11: 1-40.

Guilday, J. E. 1951. Sexual dimorphism in the pelvic girdle of Microtus pennsylvanicus. J. Mamm. 32: 216-17. 
Hall, E. R. and E. L. Cockrim. 1953. A synopsis of the North American microtine rodents. Univ. Kans. Pub., Mus. Nat. Hist. 5: 373-498.

Hamilton, Jr., W. J. 1941. Reproduction of the field mouse, Microtus pennsylvanicus (Ord). Cornell Univ. Agr. Expt. Sta., Mem. 237: 1-23.

Hansen, R. M. 1954. Molt patterns in ground squirrels. Proc. Utah Acad. Sci., Arts and Letters 31: $57-60$.

Hisaw, F. L. 1924. The absorption of the pubic symphysis of the pocket gopher, Geomys bursarius (Shaw). Am. Nat. 58: 93-6.

Howell, A. B. 1926. Voles of the genus Phenacomys. II. Life history of the red tree mouse (Phenacomys longicaudus). North Am. Fauna No. 48: 39-66.

James, W. B. and E. S. Booth. 1954. Biology and life history of the sagebrush vole. Walla Walla Coll. Pub. of Dept. Biol. and Biol. Sta., College Place, Washington, No. 4 (Revised Jan. 15, 1954): 1-21.

Kästle, W. 1953. Die Jugendentwicklung der Zwergmaus, Micromys minutus soricinus (Hermann, 1780). Säugetierkundliche Mitt. 1: 49-59.

Lyman, C. P. 1943. Control of coat color in the varying hare, Lepus americanus Erxleben. Bull. Mus. Comp. Zool. 93: 1-461.

Manning, T. H. 1954. Remarks on the reproduction, sex ratio, and life expectancy of the varying lemming, Dicrostonyx groenlandicus, in nature and capitvity. Arctic 7:36-48.

Miller, G. S. 1896. The genera and subgenera of voles and lemmings. North Am. Fauna No. 12: 1-84.

Morrison, P. R., F. A. Ryser, and R. L. Strecker. 1954. Growth and development of temperature regulation in the tundra redback vole. J. Mamm. 35: 376-386.

Selle, R. 1928. Microtus californicus in captivity. J. Mamm. 9: 93-8.

Strecker, R. L. and P. R. Morrison. 1952. Observations on lemmings from Barter Island, Alaska. J. Mamm. 33: 180-4.

Svihla, A. 1932. Notes on the meadow mouse (Microtus oregoni oregoni (Bachman)). The Murrelet 13: $94-5$. 